Accelerator Division

Alternating Gradient Synchrotron Department

BROOKHAVEN NATIONAL IABORATORY

Associated Universities, Inc.

Upton, New York 11973

Accelerator Division

Technical Note

AGS/AD/Tech. Note No. 318

\title{
BRIEF COMMENTS ON TEST RESULTS OF BOTH METAI AND ELASTOMER VACUUM SEALS
}

K.M. Welch, G.T. McIntyre, J.E. Tuozzolo, D.J. Pate

March 30,1989

Introduction

A brief over-view of the subject of sealography was given at the recent EBIS symposium held at Brookhaven. The results will be published elsewhere. However, results of metal vacuum seal tests, conducted at Brookhaven National Laboratory will be herein summarized. The note then summarizes results of work done by the first author, at the stanford Linear Acceleration Center, on the extended outgassing properties of elastomers including Viton $^{\circledR}$ and Buna $\mathrm{N}^{\circledR}$.

Considerations in selection of a Vacuum seal

When selecting a particular seal joint design for use in ultra-high vacuum (UHV) application we must make a number of compromises. Considerations which must be entertained in selecting a joint design include the: 1) reliability; 2) material outgassing rates; 3) seal permeation rate; 4) bakeability; 5) mating surface materials; 6) ease of installation; 7) required sealing force; 8) flange sizes in typical use; 9) provision for cleaning of parts; 10) initial costs; 11) operating (i.e., replacement) costs; 12) seal availability for replacement; 13) degree of radiation "hardness"; 14) shelf life; 15) handling and storage fragility; and 16) safety. Most of these 16 variables are coupled. Each was briefly discussed in the talk, but such discussion is beyond the scope of this paper. 


\section{Metal Seals}

All-metal seals are self-destructive in that they can only be reused, at most, two to three times. Common varieties of all-metal seals include the: 1) conFlat ${ }^{\circledR}$ (i.e., knife-edge); 2) Wheeler ${ }^{\circledR}$ (special wire seal); [1] 3) Foil (Al, In, Cu); 4) Wire (Al, Au, Ag, $\mathrm{Cu}$, In, etc.); 5) C-Rings, coated with soft metals; 6) C-Rings, either coated or uncoated, and reinforced w/spring materials; 7) C-Rings, with "diamond" edges, and spring reinforced (i.e., the Delta ${ }^{\circledR}$ Seal); and 8) "diamond" seals. Advantages and disadvantages of several seal configurations were discussed in the talk. Only the results of recent metal seal tests at Brookhaven will be reported. The seal configurations tested included:

A. Inconel ${ }^{\circledR}$ C-Rings, coated with In,

B. Spring reinforced, Inconel ${ }^{\circledR}$ C-Rings, jacketed with Al,

C. Spring reinforced, Incone ${ }^{(0)}$ C-Rings, coated with $\mathrm{Pb}$,

D. Spring reinforced, Incone ${ }^{\circledR}$ C-Rings, jacketed with an $\mathrm{Al}$ sheath on which "diamond" edges are machined (i.e., the Delta ${ }^{\circledR}$ seal),

E. Conventional Al "diamond" seals.

Applications at the Alternating Gradient Synchrotron (AGS) require that leak tight, all-metal vacuum seals be made with flange materials including aluminum, stainless steel and enamel coated stainless steel. For the greater part, most of the metal seals in the AGS were Type-A of the above listing. However, problems were encountered from time to time with these Inconel(8) C-Rings spontaneously cracking. Past studies indicated that such problems resulted from $\mathrm{H}_{2}$ embrittlement, due to some process in the fabrication of the seals. Also, In coated seals had very poor shelf life. oxides of In would form on the sealing surfaces, even though the seals were stored in sealed bags. Rather than "study" these problems again, we faced up to the fact that the seals were marginal, at best, and launched a study program to find a suitable alternative. 
Seals of the above listed configuration were tested. The test consisted of squeezing the seal between a stainless steel mandrel, and sealing plates made of the three different materials. The mandrel was positioned in a precision hydraulic ram. The joints were leak checked by pumping between the two plates through a hole in the bottom of the mandrel. A leak detector with a sensitivity of $1^{-10}$ Torr- $2 / \mathrm{sec}$ He was used. Any indication of a leak constituted a seal failure.

Results of these tests are given in Tables 1-4. The numbers listed vertically in the columns in the first three tables represent the number of times the seal was cycled. Stress-strain measurements, and yield data were recorded. Each time a successful seal was achieved, seal deflection was measured. Then the hydraulic ram was "released", and the seal height again measured. The plates were not parted and their respective indexing with the seal changed between each measurement. Because of this, one may not interpret the existence of successive data in any one column as indicating that the seal is reusable. However, the absence of additional data in any one column implies that the seal would not reseal on the next application of pressure. The results for the In coated c-Rings was very poor. This is because they were used "as is", on removal from the sealed bags in which they had been stored for many months. New, freshly coated C-Rings would have yielded far more reliable results. But, this is just a restatement of the initial shelf life problem.

Because of these results, the Delta ${ }^{\circledR}$ seal was adopted as the standard seal for future use in the AGS. During the 1988 summer shutdown, approximately $300 \mathrm{Del}-$ ta ${ }^{\circledR}$ Seals were used to replace the In coated, $21.6 \mathrm{~cm}$ diam. C-Rings used throughout the AGS. Problems of installation technique or inexplicable failures occurred in $\approx 3.0 \%$ of these seals at the time they were installed. However, after successful installation, there have been no failures (i.e., leaks) in these seals. 
Elastomer Seal Test Results

The most widely used elastomer seal material is Viton $A^{\circledR}$. However, where large quantities of seals (i.e., o-rings) are needed, cost considerations sometimes dictate use of another elastomer, such as Buna $N^{\circledR}$. If cost is no object, Polyimide has the best vacuum characteristics of all the elastomers. However, this material has some disadvantages. Peacock provides an excellent review paper on the properties and uses of elastomers.[2]

In tests at stanford, elastomer gasket materials were exposed to high vacuum for up to three years in duration. The purpose of these tests was to determine if there were irreversible hardness changes in the materials as a consequence of this exposure. Approximately 100 specimen o-ring segments, measuring $0.51 \mathrm{~cm}$ $\phi \times 2.5 \mathrm{~cm}$ long, were individually suspended on wire frames mounted within $\mathrm{Cu}$ pinch-off tubes. These, in turn, were welded to a large manifold pumped by a 500 L/sec sputter-ion pump. Specimens were pinched off this manifold over a three year period. The weight and hardness of each specimen was measured before and after extended immersion in high vacuum. Some samples were baked at moderate temperatures (i.e., $\approx 200 \mathrm{C}^{\circ}$ ). Numerous control samples, not exposed to vacuum, were also tested for hardness and weight changes throughout the duration of the experiment. Results of the vacuum tests were as follows:

1) All Buna $N^{\circledast}$ o-rings showed significant irreversible weight loss as a consequence of exposure to vacuum. This lost material is probably not exclusively water vapor, but rather plasticizers and polymers which would contaminate the vacuum system (e.g., plug sieve materials; poison cathodes). Irreversible weight losses in unbaked Buna- $\mathrm{N}^{\circledR}$ o-rings amounted to approximately 10 to $50 \mathrm{Atm} . / \mathrm{cm}^{3}$ of o-ring.

2) Unbaked Viton- $A^{\circledR}$ O-rings showed no significant irreversible weight loss or hardness change. Weight losses in Viton ${ }^{\circledR}$ ranged from 3 to $7 \mathrm{Atm} . / \mathrm{cm}^{3}$ of $0-r i n g$. Hardness changes in unbaked Viton- $A^{\circledR}$ were completely reversible. With baked Viton-A ${ }^{\circledR}$ o-rings, the higher 
the initial shore-A durometer hardness reading, the less the irreversible weight loss due to baking. This suggests the presence of less plasticizers and unreacted polymers in the initially harder compounds.

\section{References}

1) Roth, A., J. Vac. Sci. Technol. 9, No.1, 14 (1972).

2) Peacock, R., N., J. Vac. Sci. Technol. 17, No. 1,330 (1980).

3) Wahl, H., et. al., CERN Tech. Note SPS/81-8, December, 1981 .

4) The authors are indebted to Alain Poncet of CERN PS. Dr. Poncet provided the authors with the data which led to this study. He has extensive experience in UHV sealography, including the successful use of "diamond" seals throughout the CERN Proton Synchrotron. 


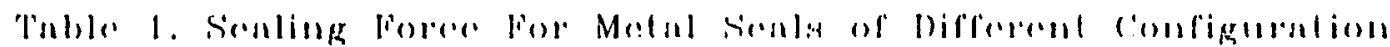
When Sealing Against l'wo Stainless steel surfaces

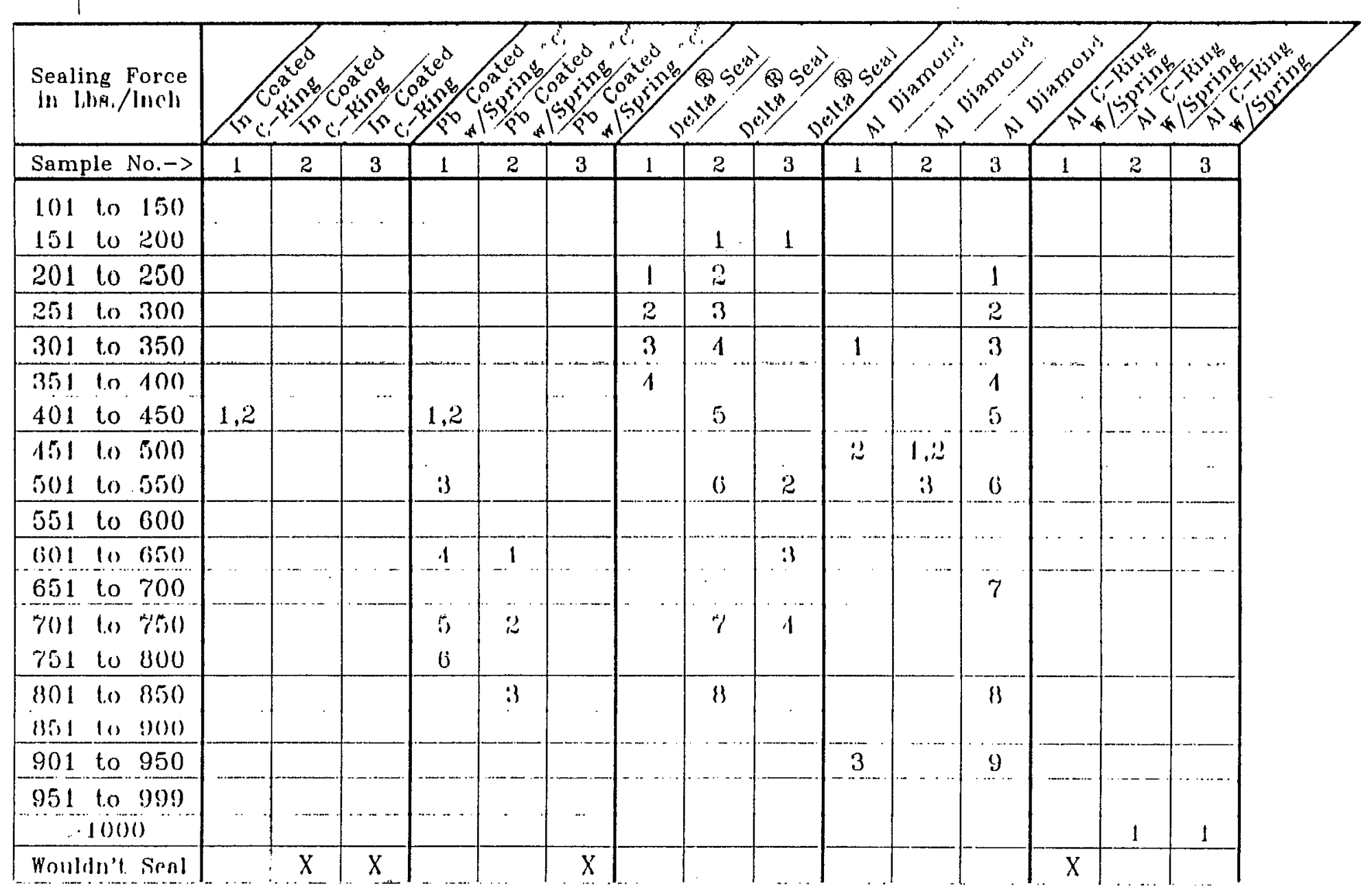


Table 2. Sealing force fror Metal Seals of Different Configuration

When Sealing Against An Aluminum and Stainless Steel Surface

\begin{tabular}{|c|c|c|c|c|c|c|c|c|c|c|c|c|c|c|c|}
\hline $\begin{array}{l}\text { Sealing Force } \\
\text { in Lbs./Inch }\end{array}$ & & & & & & & & & & & & & & & \\
\hline Sample No. $\rightarrow$ & 1 & 2 & 3 & 1 & 2 & 3 & 1 & 2 & 3 & 1 & 2 & 3 & 1 & 2 & 3 \\
\hline 101 to 150 & & & & & & & & 1 & & & & & & & \\
\hline 151 to 200 & & & & & & & 1 & 2 & 1 & & & & & & \\
\hline 201 to 250 & & & & & & & 2 & 3 & 2 & & & & & & \\
\hline 251 lo 300 & & & & & & & & & 3 & & 1 & & & & \\
\hline $301 \quad 10 \quad 350$ & & & & & & & 3 & & 1 & & & & & & \\
\hline 351 to 400 & & & & & & & & & & & & & & & \\
\hline 401 to 450 & & & & 1 & & 1,2 & 4 & & 5 & & 2 & & & & \\
\hline 451 lo 500 & & & & & & & & & & & & & & & \\
\hline 501 to 550 & & & & 2 & 1,2 & 3 & & 4 & & 1 & 3 & & & & \\
\hline 551 to 600 & & & & & & & & $\ldots$ & & & & .. & & $\ldots$ & \\
\hline 601 to 650 & & . & & 3 & 3 & 4 & & & & & 4 & & & & \\
\hline 651 to 700 & & & & & & & & & & 2 & & 1 & & & \\
\hline 701 to 750 & & & & 4 & 4 & 5 & 5 & 5 & & & & & & & \\
\hline 751 10 800 & & & & & & & & & & & & & & & \\
\hline 001 10 850 & & $\ldots$ & $\ldots$ & 5 & 5 & i & & (i) & & & 5 & $\therefore$ & & & $\ldots$ \\
\hline 851 to 900 & & & & & & & & & & & & & & & \\
\hline $\begin{array}{lll}901 & \text { to } & 950() \\
951 & \text { to } & 999\end{array}$ & & & & & & & & & & & (; & & & & \\
\hline $\begin{array}{c}\because 1000 \\
\text { Wouldn't seal }\end{array}$ & $x$ & $x$ & $x$ & & & & & & & 3 & & & $x$ & $x$ & $x$ \\
\hline
\end{tabular}


Table 3. Sealing force fror Melal beals of Diflerent configuration

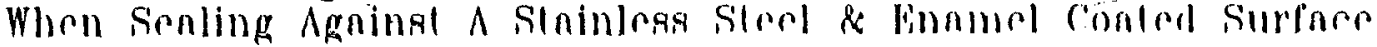

\begin{tabular}{|c|c|c|c|c|c|c|c|c|c|c|c|c|c|c|c|}
\hline \multicolumn{16}{|l|}{$\begin{array}{l}\text { Senling Foree } \\
\text { la libs./lneh }\end{array}$} \\
\hline Sinmulln $\quad N(1,-\cdot$ & 1 & $:$ & : & 1 & $\therefore$ & $: 1$ & 1 & $: 3$ & 3 & 1 & $:$ & i) & 1 & $:$ & : \\
\hline 101 to 150 & & & & & & & & & & & & & & & \\
\hline 15110200 & $\ldots$ & & & & & & & & 1 & . & & & & & \\
\hline 201 to 250 & & & & & & & 1 & 1 & 2 & & & & & & \\
\hline 251 to 300 & & & & & & & & 2 & & & & & & & \\
\hline 301 lo 350 & & & & & & & & & i) & & & & & & \\
\hline 351 lo 400 & & & & & & & 2 & 3 & 4 & & & & & & \\
\hline 10110.150 & & & & & & $\ldots$ & & &.$\ldots$ & & & & & & \\
\hline 451 to 500 & & & & & & & & & & 1 & & & & .. & \\
\hline 501 to 550 & & & & 1 & & & 3 & & 5 & & & & & & \\
\hline 551 lo 600 & & & & & & & & & & & & & & & \\
\hline 601 t.o 650 & & & & 2 & & & 4 & 4 & & & $\cdots$ & & & & \\
\hline 0551 lo 700 & & & & & & & & & & $\therefore$ & & & & & \\
\hline 701 to 750 & & & & & & & 5 & 5 & 6 & & & & & & \\
\hline isil (1) (1) & & & & & & & & & & & & & & & \\
\hline 1301101350 & & & & 3 & & & (j) & & & & 1 & & & & \\
\hline 851 t.o 900 & & & & & & & & & & & & & & & \\
\hline $901 \quad 10 \quad 950$ & & & & & & & & & & & & & & & \\
\hline 9501 (6) & & & & & & & & & & - & & & & & \\
\hline .1000 & & & & & & & & & & & $\because 3$ & & & & \\
\hline Wouldu't Sinnl & $X$ & $X$ & $X$ & & $-x$ & $\mathrm{X}$ & & & & & & $x^{\prime}$ & $x$ & $x$ & $x$ \\
\hline
\end{tabular}




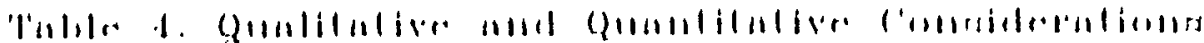

In the selection of a Vacumm Seal Configuration.

\begin{tabular}{|c|c|c|c|c|c|c|c|c|c|}
\hline $\begin{array}{l}\text { Vacuum Seal } \\
\text { Configuration }\end{array}$ & $\begin{array}{c}\text { Sealing } \\
\text { Force } \\
\text { l, s. /Inch }\end{array}$ & $\begin{array}{l}\text { Bakeable } \\
(\text { yos, no })\end{array}$ & $\begin{array}{c}\text { Bakeout } \\
\text { 'temp. (c) }\end{array}$ & $\begin{array}{l}\text { Reuseable } \\
(y(\text {. no })\end{array}$ & $\begin{array}{l}\text { Maximuin } \\
\text { Flange Diam. } \\
\text { linchess }\end{array}$ & $\left(\begin{array}{c}\text { Cost } \\
(I=I \| g h)\end{array}\right)$ & $\begin{array}{c}\text { Reliability } \\
\left(1=\| 1 I_{g} h\right)\end{array}$ & $\begin{array}{l}\text { Shelf } \\
\text { Life }\end{array}$ & $\begin{array}{l}\text { Fragility } \\
(1=\|\| g h)\end{array}$ \\
\hline Conflat ${ }^{2}$ Gasket & $1350^{1}$ & YES & 625 & No & 10 & 3 & 1 & GOOD & 5 \\
\hline Wheeler ${ }^{\mathbb{B}}$ Gasket & $>1500^{2}$ & YES & 450 & No & 30 & 1 & 2 & GOOD & 4 \\
\hline $\begin{array}{ll}\text { Indium } & \text { Coated } \\
\text { Inconel C-Ring } \\
\end{array}$ & $<400$ & NO & - & $?$ & $>30$ & 2 & 7 & POOR & 4 \\
\hline $\begin{array}{l}\text { Al fuckert li-king, } \\
\text { Spring Reinforced }\end{array}$ & 1000 & NO & - & No) & $\therefore 80$ & 4 & 7 & $(i(0) 1)$ & 4 \\
\hline $\begin{array}{l}\text { Pb Coated C-Ring } \\
\text { Spring Reinforced }\end{array}$ & $400-600$ & $?$ & $?$ & $?$ & 30 & 2 & 3 & $\mathrm{POOR}$ & 3 \\
\hline $\begin{array}{l}\text { Al Della }{ }^{\text {fo }} \text { C-Ring } \\
\text { Spring Reinforced }\end{array}$ & $100-250$ & YES:" & $2000^{i 1}$ & YWS & 40 & 4 & 2 & $(\mathrm{iOOD})$ & 1 \\
\hline Dinmond, & $200-800$ & NO & - & NO) & .10 & $5^{4}$ & :) & $(i() 0))$ & $\therefore$ \\
\hline
\end{tabular}

